\title{
Assessment of Hydro Potential Using Integrated Tool in QGIS
}

\author{
Indrajeet Sahu ${ }^{1, *}$, A D Prasad ${ }^{1}$ \\ ${ }^{1}$ Department of Civil Engineering, National Institute of Technology Raipur, India - iamindraa14@gmail.com
}

Commission V, WG V/8

KEY WORDS: Hydro potential, Integrated tool, QGIS, watershed.

\begin{abstract}
:
The necessity for developing Hydropower plants a renewable energy source has emerged due to increase in energy demand and environmental concern, as non-renewable sources produce greenhouse gasses. Location analysis methodology for hydropower development has formerly depended upon onsite surveys and manual work which are tedious, time consuming and costly as compared to the work done on GIS environment. In current study an attempt has been made to construct a tool that integrate and automate the various hydrology tools available in QGIS for finding hydro potential site. Each tool perform different function and are linked according to the workflow as majority of these tools uses the output of the previous tool and thus are interdependent. Geoprocessing analysis is performed on DEM to generate fill sink, flow direction, flow accumulation, identification of stream network, head (falling height). Hydrological data (runoff) and Pour point location is taken as input to generate discharge value and watershed contributing to that point location respectively. Finally hydro potential is calculated by the tool and sites having high potential are identified. The model is tested on Hasdo bango hydro power plant site located in Korba district of Chhattisgarh. The hydro potential of the site evaluated from the model is $112 \mathrm{MW}$ which is close to the total installed capacity of the existing hydro power plant of $120 \mathrm{MW}$.
\end{abstract}

\section{INTRODUCTION}

The energy demand in India is mainly obtain from Nonrenewable resources (coal, gas, oil), contributing about $64.8 \%$ of total energy production (Central Electricity Authority (CEA), 2018). Considering fossil fuel resource diminution, global concern related to climate change mitigation and high import prices. The optimization of low carbon electricity through alternative renewable energy source and the importance of clean energy should be considered. Hydropower provides one of the most environmentally clean forms of energy with the least emissions of greenhouse gases among all the types of new and renewable energy (Choong-Sung Yi, 2010). It is also expected that sufficient amounts of alternative energy could be potentially provided by hydropower generation, where there is an abundance of potential sites and efforts are being made to reduce the consumption of fossil fuels. It has been reported that in India only $16.6 \%$ of the total potential hydro energy have been utilized with $25 \%$ share of the country's energy demand (Dudhani S, 2006).

In developing countries like India, the development of small scale hydropower is well achievable as the country is having abundant free falling water with stream networks in many regions. The country's topography and landscape is such that it offer the possibility of having hydro potential site (Kishor N, 2007). Currently there is a rise in demand for electricity and government is unable to find low cost solution to accomplish the demand as it is highly populated country.

Complex hydrological phenomena and the inaccessibility of Hydro potential (HP) sites which are mostly in hilly regions, remain barriers that obscure the assessment effort and make it time consuming, and lead towards larger investment (Grett, J. P, 2014). However, with the advancement of geospatial technology and remote sensing together with hydrological and hydraulics modelling it is possible to optimize the assessment of HP.

GIS and remote sensing applications were utilized for identifying potential sites within the Hasdeo river catchment area which comes under Korba district of Chhattisgarh. Important features of catchment like; elevation, rainfall, stream network, watershed delineation, soil, and land use/land cover (LULC) were evaluated and integrated into GIS environment for obtaining potential sites for hydropower installation (Tingneyuc Sekac, 2017).

To locate hydropower opportunities, reliable elevation data, landuse, land-cover and precipitation data are required (Patil NS, 2013). The understanding of topographical settings, stream network and catchment area are the important factors needed in the initial stage of site identification. The key factors to be considered during assessment are stretch of the catchment area, runoff rate within the catchment area, head (falling height), density of water $\left(1000 \mathrm{~kg} / \mathrm{m}^{3}\right)$ and gravitational pull $\left(9.8 \mathrm{~m} / \mathrm{s}^{2}\right)$ (Feizizadeh B, 2012).

Preparation of model were carried out using Geographical Modelling module in an open source QGIS computer software tools. The result from analysis show suitable power potential in Mw including specific sites.

\section{STUDY AREA}

Korba district got the status of a full-fledged revenue district with effect from 25 May, 1998. Korba district is situated in the northern half of the Chhattisgarh state and surrounded by the districts Korea, Surguja, bilaspur, Janjgir etc. Korba is the power capital of Chhattisgarh. The district comes under Bilaspur division. The District's total area is 7,14,544 hectare out of which $2,83,497$ hectares is forest land and it is located between $22^{\circ} 01^{\prime}$ to $23^{\circ} 01^{\prime}$ North and $82^{\circ} 07^{\prime}$ to $83^{\circ} 07^{\prime}$ East (Fig.1).

\footnotetext{
${ }^{*}$ Corresponding author
} 


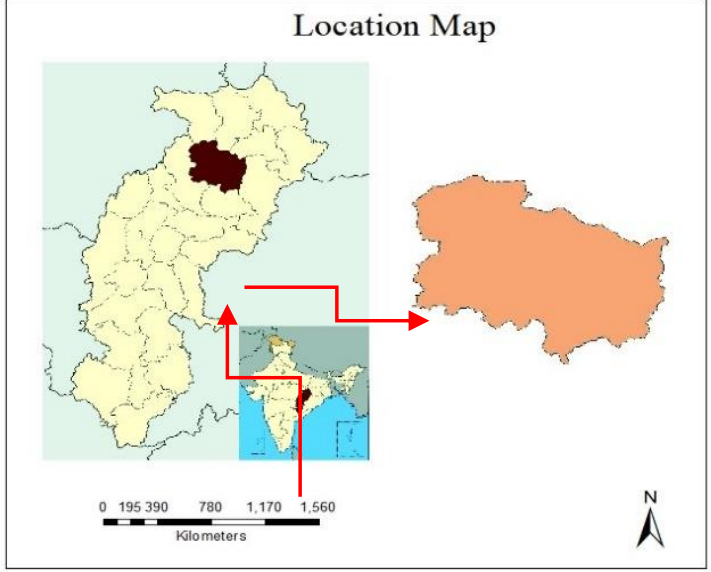

Figure 1. Korba district location map.

Korba District falls under the hot temperate climate zone. Rainy season due to the South-West Monsoon is from mid-June till the end of September. The average rainfall in the district is $1287.6 \mathrm{~mm}$ (Korba district administration, 2017). The main river which is flowing through Korba district is the Hasdeo river start from Pathar in the Valley of Chhota Nagpur. The total length of this river is 233 $\mathrm{km}$. Its tributaries are Gagechorai, Tan and Ahiran.

\section{METHODOLOGY}

Since a DEM file can have inaccuracy causing creation of sink area in the result, for that DEM reconditioning is required, by applying FILL tool which produces sink less DEM raster file as output. Flow Direction tool determines and creates a raster of the natural drainage direction for every pixel in a DEM to its steepest down slope neighbour. The input is the DEM raster file and the output is a raster with each pixel illustrating a direction in the form of a colour (8 directions).

Flow Accumulation tool creates a raster of accumulated flow into each cell. The input for the tool is flow direction map and the output obtain is a raster which counts the total number of pixels that will drain into outlets. Thus the higher value indicates more accumulation and can be identified as a potential water stream.

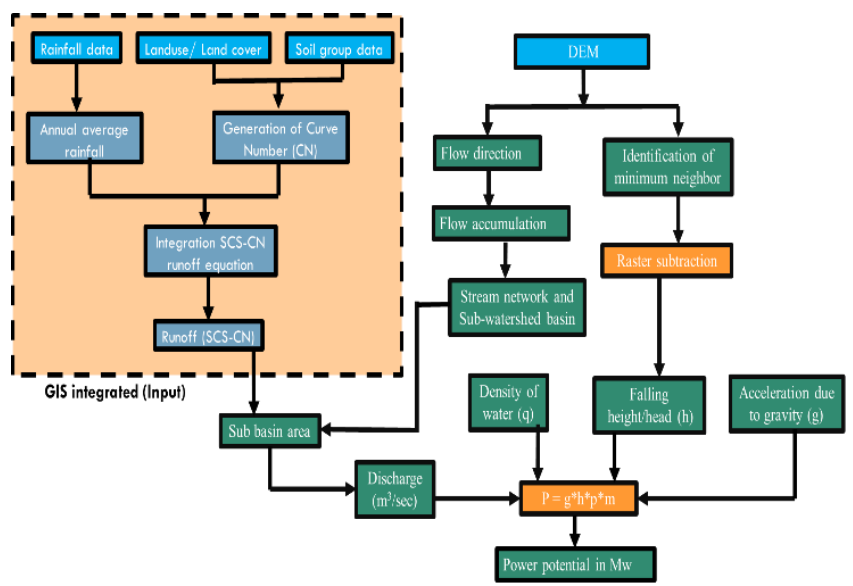

Figure 2. Workflow of the hydro potential model.

To obtain discharge, runoff of the catchment area is required which will be calculated using Soil Conservation Service (SCS) model developed by United States Department of Agriculture (USDA) computes direct runoff through an empirical equation which requires the rainfall and a watershed coefficient as inputs. The watershed coefficient is called as the Curve Number (CN). This model involves relationship between land cover, hydrologic soil class and curve number (Adornado, H. A, 2010). The annual runoff calculation was approached using the formula (Eq.1);

$$
Q=\frac{(P-I a)^{2}}{(P-I a+S)}
$$

Where $\mathrm{Q}=$ actual annual runoff $(\mathrm{mm}), \mathrm{P}=$ average annual rainfall $(\mathrm{mm}), \mathrm{S}=$ potential maximum retention, $\mathrm{Ia}=0.2 \mathrm{~S}$ initial abstraction $(\mathrm{mm})$. This is the loss of water before runoff begins by soil and vegetation in a form of infiltration. The constant value of 0.2 was used for Korba.

The potential maximum retention $(S)$ was calculated by involving $\mathrm{CN}$ and the constant value. Equation below is used for calculation (Eq. 2).

$$
S=\frac{25400}{C N}-254
$$

$\mathrm{CN}=$ curve number of hydrologic soil and is the function of soil type, Landuse and Land cover (LULC) and antecedent moisture condition (AMC).

The final output from all these calculation was the annual runoff in millimetre $(\mathrm{mm})$ which was then integrated with watershed area to obtain cubic metre $\left(\mathrm{m}^{3}\right)$ of river discharge. The river discharge within a sub-watershed is then divided by $3,153,600$ (total seconds in a year) to get the output unit in $\mathrm{m}^{3} / \mathrm{s}$.

It is integrated in GIS environment and CN II map (Fig 4) is developed along with discharge map (Fig. 8) and taken as an input for the model tool.

The head calculation was carried out using ASTER $30 \mathrm{~m}$ spatial resolution Digital Elevation Model (DEM) within QGIS environment. Firstly the DEM was used in "r.neighbor" tool to calculate the nearest neighbour. The nearest neighbour output data were then subtracted from original DEM data using raster calculator to get drop in elevation.

Hydropower potential development sites were quantified by calculating certain power outputs at potential site. The power potential $(\mathrm{P})$ in Watts $(\mathrm{W})$ was calculated using (Eq 1).

$$
\mathrm{P}=\mathrm{q} * \mathrm{~m} * \mathrm{~g} * \mathrm{~h} .
$$

Where, $\mathrm{P}=$ power potential $(\mathrm{W}), \mathrm{q}=$ density of water $(1000$ $\left.\mathrm{kg} / \mathrm{m}^{3}\right), \mathrm{m}=$ annual discharge $\left(\mathrm{m}^{3} / \mathrm{s}\right), \mathrm{h}=$ falling height or head $(\mathrm{m}), \mathrm{g}=$ acceleration due to gravity $\left(9.81 \mathrm{~m} / \mathrm{s}^{2}\right)($ Kusre BC, 2010).

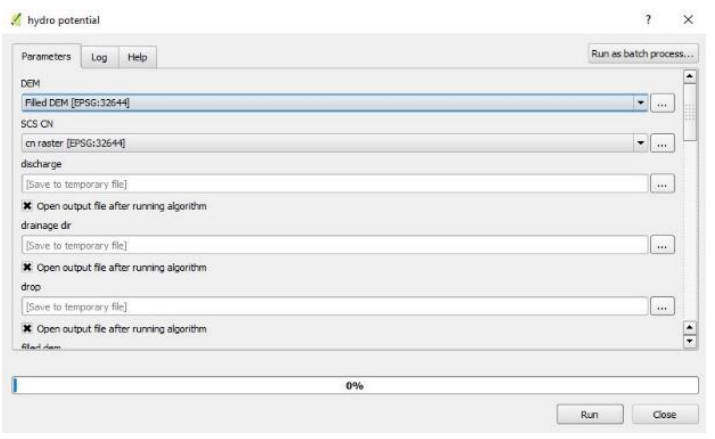

Figure 3(A). Graphical user interface of hydro potential model 


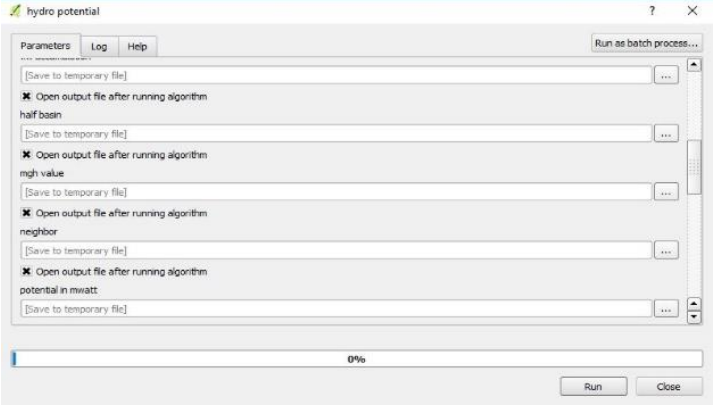

Figure 3(B).Graphical user interface of hydro potential model.

The tool is developed by geographical modelling tool in QGIS open source software (QGIS Development Team, 2017) Fig.3 (A) and (B) shows graphical user interface (GUI) of the model where input are entered along with output files name and directory location where file is to be saved. The final results were considered for determining the suitable sites for hydropower plant development. The output was in Watts and later changed to Megawatts.

\section{RESULTS AND DISCUSSION}

The tool performs its function efficiently and produces separate directories for every input file. The GUI is such that it saves only those which are selected by the user in the tool GUI. By this it avoids saving of some intermediate files which are not required by the user and reduces wastage of storage space. Since the tool integrates many tools in one master tool it significantly reduces effort and time used for such analysis.

One of the common factors involved in hydropower potential determination is the falling height of river/streams. The nearest neighbour output data were subtracted from original DEM data to get head drop having ranges from 0 to 182 (Fig. 6). A pour point is selected where the entire water drains and a sub watershed is obtain for that point. With the runoff data and the watershed area (Fig. 7), discharge for the sub-watershed is obtained by runoff value and the area contributing to that is in between 30 cumec to 46 cumec (Fig 8 ) which will be further use to calculate power potential.

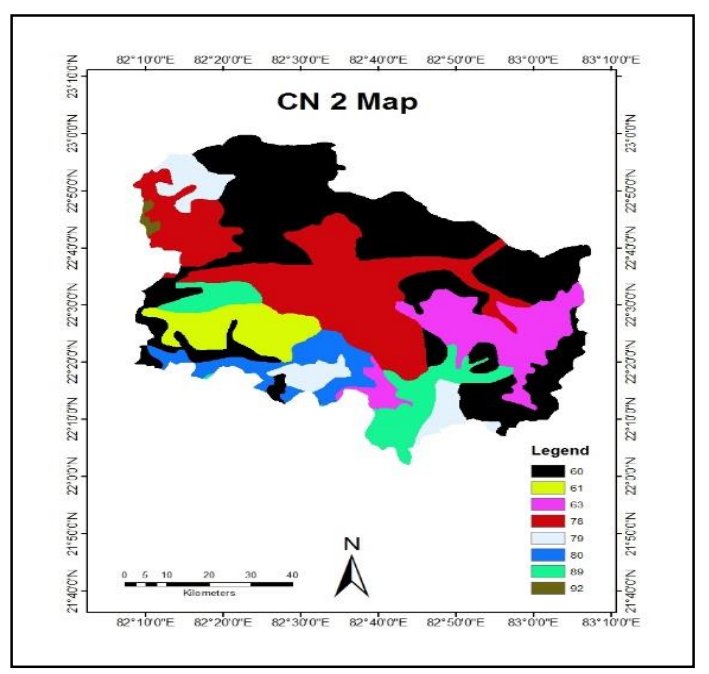

Figure 4. Gurve number (CN II) map

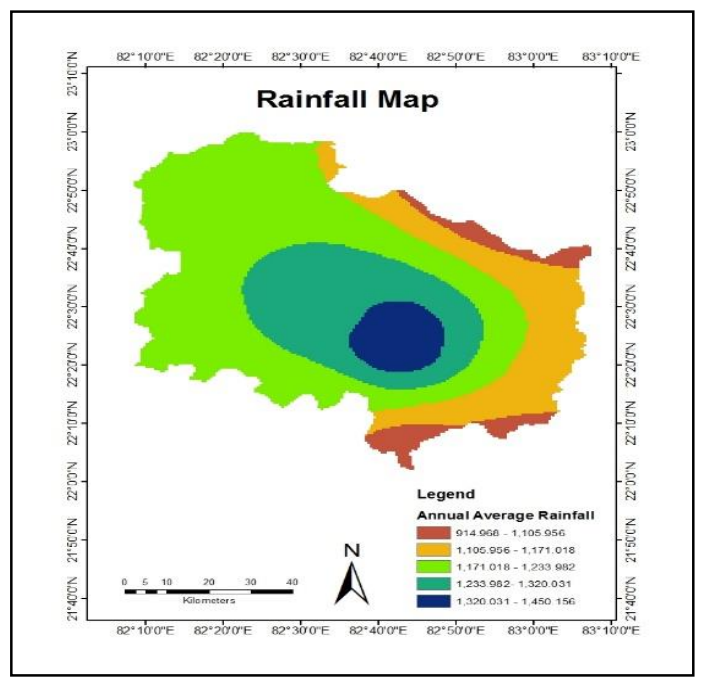

Figure 5. Annual average rainfall map

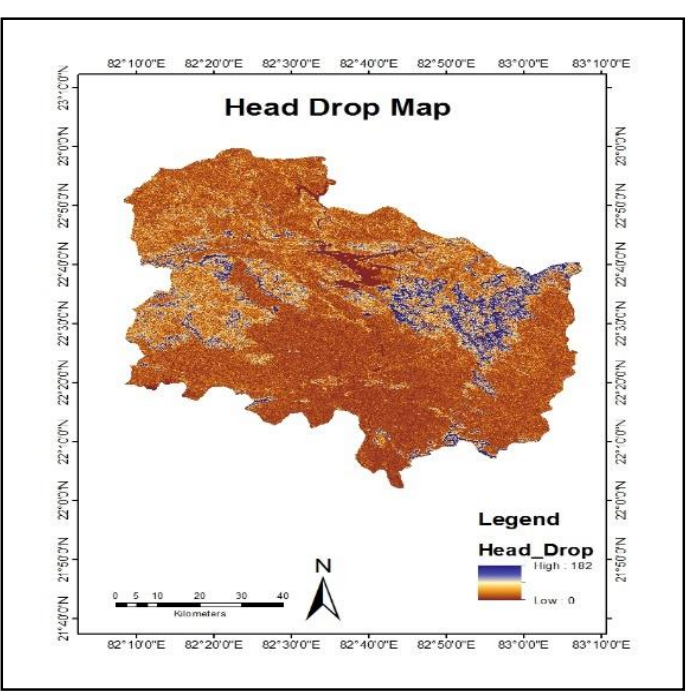

Figure 6. Head drop/Falling height map

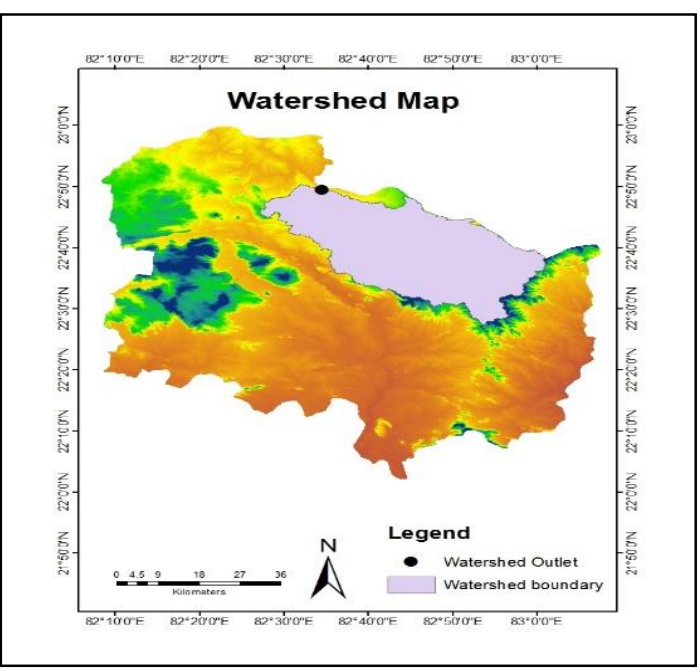

Figure 7. Watershed for the given outlet point map 


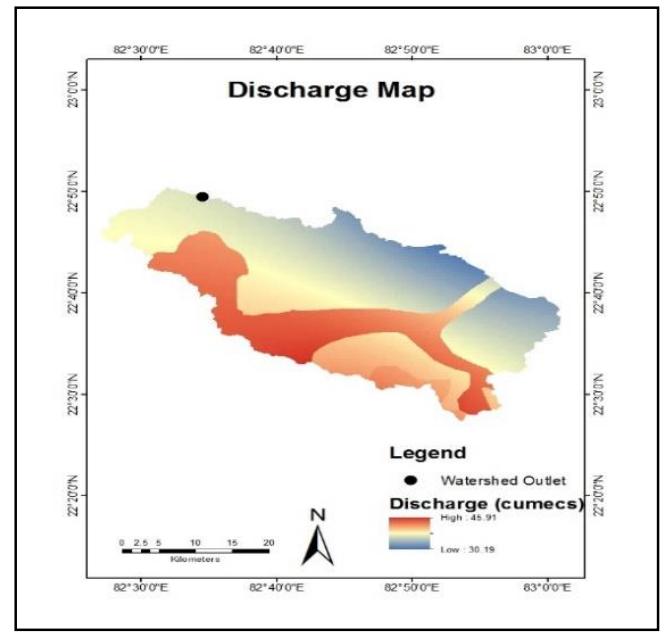

Figure8. Watershed discharge map.

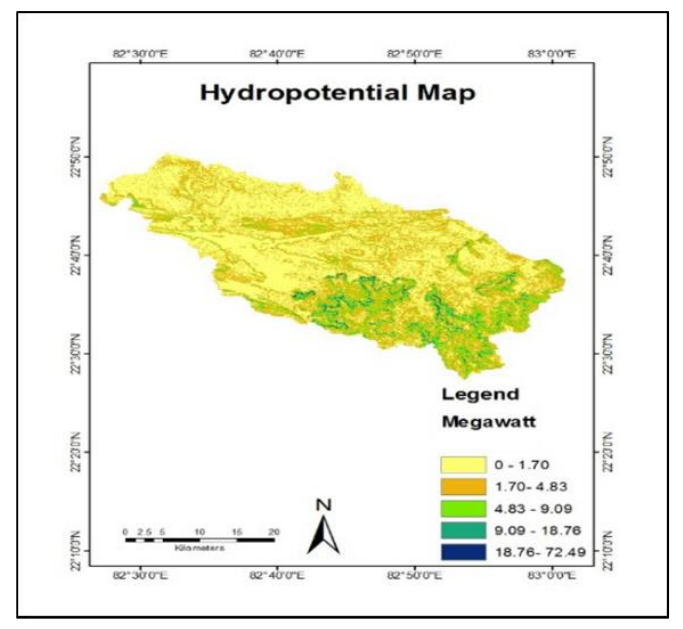

Figure 9. Hydro potential map of the desired watershed.

The power potential $(\mathrm{P})$ was calculated using the formula; $\mathrm{P}=\mathrm{q}$ $* \mathrm{~m} * \mathrm{~g} * \mathrm{~h}$. Calculated results shows that hilly area is having maximum power potential up to $72 \mathrm{Mw}$ as height (head drop) is one of the main factor included in it and site which are suitable for hydropower development are having power potential up to 18 Mw (Fig.9).

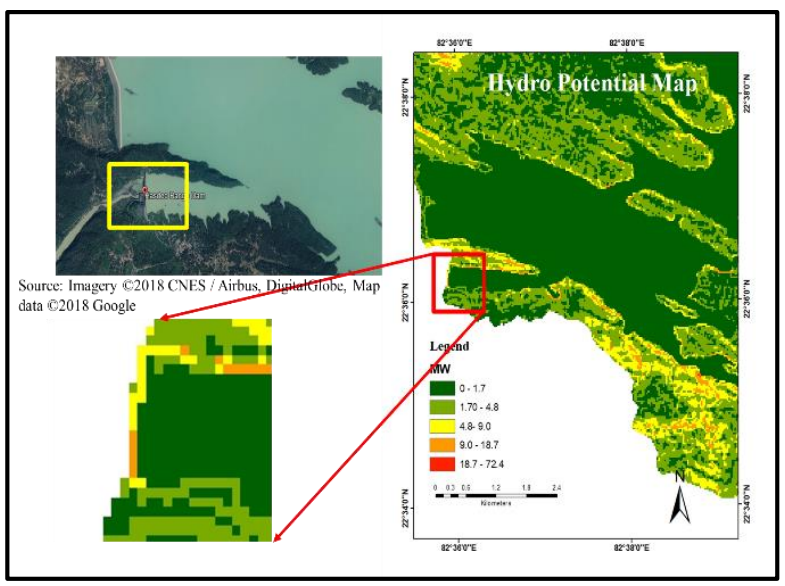

Figure 10. Hasdeo bango dam with hydro potential cell value.
The model has been evaluated to find out the hydro potential of the Hasdeo bango dam. The total capacity of $112 \mathrm{MW}$ is obtain from the result of the model tool (Fig 10). The existing hydro power plant Hasdeo bango dam is having total installed capacity of 120MW (India-WRIS 2018). On comparing the output of the model tool with the existing one it is found out to be having an accuracy of $93 \%$ which is quite good for the model tool.

\section{CONCLUSION}

The tool discussed in this study is automated tool which requires some initial data such as DEM, watershed pour point and runoff value for assessment of the result. Every topographical feature, stream network, catchment area, runoff capacity within the catchment area was assessed and potential sites were identified with specific power capacity. Also this tool is much faster than the conventional method were various tools are used separately for getting different parameter and thus creates an error free workflow with no chances of mistakes.

The calculated power output in MW at different sites are to show that the identified sites were capable of producing such output. Higher accuracy of the model and detailed evaluation of potential site for power plant development are achieved by using further data sources like high resolution images and terrain data.

\section{REFERENCES}

Adornado, H. A. and Yoshida : GIS-based watershed analysis and surface run-off estimation using curve number $(\mathrm{CN})$ value. : J. Environ. Hydrol. 18, 1-10, (2010).

Central Electricity Authority (CEA) Total Installed Capacity. http://www.cea.nic.in/monthlyinstalledcapacity.html (As on 31.03.2018).

Choong-Sung Yi, Jin-Hee Lee, Myung-Pil Shim. "Site location analysis for small hydropower using geo-spatial information system", Renewable Energy, (2010).

Dudhani S, Inamdar SS, Sinha AK. : Assessment of small hydropower potential using remote sensing data for sustainable development in India. Energy Policy;34:3195-205 (2006).

Feizizadeh B, Haslauer EM. : GIS-based procedures of hydropower potential for Tabriz basin, Iran. : Proceeding of $6^{\text {th }}$ Geoinformatics Forum July 3-6, 2012 Salzburg, Austria; 495502 (2012)

Grett, J. P., \& Fay, T.: Small hydropower potential assessment using remote sensing and hydrological data-The hydro minds model. : Technical report and model presentation. Geo mindsgeosolutions and consulting, Ippendorfer Allee 9453127 Bonn, (2014).

India-WRIS (Water Resource System of India), Hasdeo Bango Power House. http://indiawris.nrsc.gov.in/wrpinfo/index.php?title=Hasdeo_Bango_Powe r_House_PH01576. (As on 28.04.2018). 
Korba district administration, Government of Chhattisgarh. http://korba.gov.in/en/about-district, (Page last updated: 20-092017).

Kusre BC, Baruah DC, Bordoloi PK, Patra SC. : Assessment of hydropower potential using GIS and hydrological modeling technique in Kopili River basin in Assam (India). : Applied Energy 87: 298-309 (2010).

Patil NS, Shirkol IT, Joshi SG. : Geospatial Technology for Mapping Suitable Sites for Hydro Power Plant. : International Journal of Innovative Technology and Exploring Engineering (IJITEE): 2278-3075 (2013).

QGIS Development Team, 2017. Quantum Geographic Information System (QGIS) software version 2.18.13. Open Source Geospatial Foundation (OSGeo). https://qgis.org/en/site/about/index.html

Tingneyuc Sekac, Sujoy Kumar Jana, Dilip Kumar Pal. "Identifying potential sites for hydropower plant development in Busu catchment: Papua New Guinea", Spatial Information Research, (2017). 